\title{
The Effects of Watermelon Rind Flour on the Functional and Proximate Properties of Wheat Bread
}

\author{
C. Imoisi ${ }^{1}$, J.U. Iyasele ${ }^{1}$, U.C. Michael ${ }^{2}$ and E.E. Imhontu ${ }^{3}$. \\ ${ }^{1}$ Department of Chemistry, University of Benin, Benin City, Edo State, Nigeria \\ ${ }^{2}$ Department of Science Laboratory Technology, Delta State Polytechnic, Otefe-Oghara, Delta State, \\ Nigeria \\ ${ }^{3}$ Department of General Studies, Edo State School of Health Technology, Benin City, Edo State, \\ Nigeria \\ *Corresponding Author: imoisi.chinyere@gmail.com, +2347030746386 \\ Received 28 February 2020; accepted 29 June 2020, published online 04 September 2020
}

\begin{abstract}
The present study was undertaken to develop bread from composite flours. Composite flours were prepared by blending wheat flour with watermelon rind flour in ratios of 100:0 $\left(\mathrm{AB}_{1}\right)$, 90:10 $\left(\mathrm{AB}_{2}\right)$, 80:20 $\left(\mathrm{AB}_{3}\right), 70: 30\left(\mathrm{AB}_{4}\right)$ and 60:40 $\left(\mathrm{AB}_{5}\right)$, respectively. This study was carried out to ascertain the effects of watermelon rind flour at different replacement levels $(0 \%, 10 \%, 20 \%, 30 \%, 40 \%)$ on the proximate and functional properties of composite wheat bread. The results of proximate properties determination on wheat/flour blend gave low bulk densities of $0.54 \mathrm{~g} / \mathrm{cm}^{3}$ to $0.60 \mathrm{~g} / \mathrm{cm}^{3}$, high water absorption capacity of 2.389 to $3.044 \mathrm{~g} / \mathrm{g}$ as well as a high swelling capacity of 5.764 to $7.610 \mathrm{~g} / \mathrm{g}$ and a low oil absorption capacity of 1.608 to $2.150 \mathrm{~g} / \mathrm{g}$. The results of proximate composition of composite bread revealed an increase in \% protein, \% carbohydrate and \% ash from $15.7 \%$ to $18.8 \%, 47.1 \%$ to $52.0 \%$ and $0.6 \%$ to $1.2 \%$ respectively and a subsequent decrease in $\%$ fat from $18.4 \%$ to 13.8 . There was a reduction in energy density for composite bread. The functional properties of composite flours such as swelling capacity, water absorption capacity, oil absorption capacity and bulk density were increased with increase in the incorporation of watermelon rind flour with wheat flour. Thus, the results indicate that by incorporating watermelon rind flour, it is possible to enhance the nutritional quality, chemical and functional properties of bread.
\end{abstract}

Keywords: Absorption capacity, bulk density, chemical properties, replacement levels and swelling capacity.

\section{Introduction}

Composite flours may be considered firstly as blends of wheat and other flours for the production of leavened breads, unleavened baked products, pastas, porridges, snacks foods and cakes; or secondly, wholly non-wheat blends of flours or meals, for the same purpose. Sometimes, only flour is used as replacement-for example, tortillas and wheatless bread from sorghum, pastas from sorghum or maize. The composite flour for staple foods such as baking items, it should be noted that there are two reasons for mixing the wheat with other flours i.e. economic and nutritional. Using blends, now called composite flours (CF), of wheat and other flours for bread making has always occurred in times of scarcity of wheat, from whatever cause, climatic or economic. As ingredients are being blends in composite flour may be cassava, maize, rice, sorghum, the millets, potato, barley, sweet potato and yam. In selecting raw materials for use as alternatives one must consider factors, such as (a) Compatibility- that is to say, suitability for end use and (b) availability and cost at point of use [1]. Composite flours are quite different from the ready-mixed flours familiar to millers and bakers. Whereas ready-perishable constituents of the recipe for certain baked products. Composite flours are only a mixture of different vegetables flours rich in starch or protein, with or without wheat flour, for certain groups of bakery products. This gives rise to the following definition: "Composite flours are a mixture of flours from tubers rich in starch 
(e.g. cassava, yam, sweet potato) and/or protein rich flours (e.g. soy, peanut) and/or cereals (e.g. maize, rice, millet, buckwheat), with or without wheat flour". In another words, "A flour made by blending or mixing varying proportion of more than one non-wheat flour with or without wheat flour and used for production of leavened or unleavened baked or snack products that are traditionally made from wheat flour and increase the essential nutrients in human diet is called composite flour". Functional properties are the fundamental physicochemical properties that reflect the complex interaction between the composition, structure, molecular conformation and physicochemical properties of food components together with the nature of environment in which these are associated and measured [2]. Functional characteristics are required to evaluate and possibly help to predict how new proteins, fat, fibre and carbohydrates may behave in specific systems as well as demonstrate whether or not such protein can be used to stimulate or replace conventional protein [3].

The bread available in the market are prepared from wheat flour which lacks in good quality protein because of its deficiency in lysine; and dietary fibre contents. Watermelon rind flour is highly nutritious in protein, vitamin, minerals and lysine content has been found for its incorporation into preparation of bread. The study provides the information about a commercially viable application of increasing protein and fibre content in bread and also this can solve the problem of malnutrition and other essential macro and micro nutrients deficiency among the population. The objective of the present study was also to expand the utility of watermelon rind flour by value addition through incorporation with wheat flour to prepare the composite flour and used to develop the bread and their characterization. Little work has been reported on the study of the functional properties of flours, bread made from composite flour watermelon rind flour.

\section{Materials and Methods}

\section{Study Area and Sites}

Benin City is a city found in Edo State, Nigeria. It is located $6.34^{\circ} \mathrm{N}$ latitude and $5.63^{\circ}$ E longitude and it is situated at elevation 88 metres above sea level. Benin City has a population of $1,125,058$, making it the biggest city in Edo State.

\section{Study Design}

Preparation of Bread and Incorporation with Watermelon Rind Flour

Bread was produced using the straight dough process. Baking was carried out under laboratory conditions to optimize baking conditions. Flour and watermelon rind fiber weighing were carried out on a laboratory scale. Dough was mixed to optimum consistency in a mixer with low speed 85rpm for 1 minute. The substitution of wheat flour by watermelon rind flour was $0 \%, 10 \%, 20 \%$, $30 \%$ and $40 \%$ for $\mathrm{AB}_{1}, \mathrm{AB}_{2}, \mathrm{AB}_{3}, \mathrm{AB}_{4}$ and $A B_{5}$. Fiber and other ingredients for bread were accurately added and the sugar and yeast. The mixed cream was then put into medium size round calibrated pan. The bread was oven baked for 1 hour 25 minutes at $100^{\circ} \mathrm{C}$.

\section{Sample Collection and Analysis}

Wheat was purchased at Uselu and new Benin local market, Benin City, $7 \mathrm{~kg}$ wheat was weighed with a weighing balance in the laboratory and washed severally before soaking with 7litres of water overnight, thereafter, the wheat was grinded with a grinder and subsequently sieved with a soft cloth sieve. The sieved wheat was sundried for seven days thereafter it was grinded again and subsequently sieved with a smaller sieve to obtain a fine wheat flour powder.

Watermelon was purchased at new Benin local Market, the pulp was removed to obtain the rind (peel). The watermelon rinds were thoroughly washed under tap water and then sliced into pieces with stainless steel knives on trays and sundried for 7days. Grinding first in an electric mill before using a grinder to obtain fine rind powder of larger surface area. The 
fine powder was then stored in a closed container until experiment commenced.

\section{Data Analysis \\ Evaluation of Functional Properties of Flours}

The functional properties of flours were analyzed i.e. Swelling capacity $(\mathrm{g} / \mathrm{g})$, water absorption capacity (WAC, g/g), oil absorption capacity $(\mathrm{OAC}, \mathrm{g} / \mathrm{g})$, and Bulk density $\left(\mathrm{g} / \mathrm{cm}^{3}\right)$. The swelling capacity was determined by the method described by Okaka and Potter [4]. 100 $\mathrm{mL}$ graduated cylinder was filled with the sample to $10 \mathrm{~mL}$ mark. The distilled water was added to give a total volume of $50 \mathrm{~mL}$. The top of the graduated cylinder was tightly covered and mixed by inverting the cylinder. The suspension was inverted again after $2 \mathrm{~min}$ and left to stand for a further $8 \mathrm{~min}$. The volume occupied by the sample was taken after the $8^{\text {th }}$ min.

The water absorption capacity of the flour was determined by the method of Sosulski et al. [5]. One gram of sample mixed with $10 \mathrm{~mL}$ distilled water and allow to stand at ambient temperature $\left(30 \pm 2^{\circ} \mathrm{C}\right)$ for $30 \mathrm{~min}$, then centrifuged for $30 \mathrm{~min}$ at 3,000 rpm or $2000 \times$ g. Water absorption was examined as mass of water bound per gram flour.

The oil absorption capacity was also determined by the method of Sosulski et al. [5]. One gram of sample mixed with $10 \mathrm{~mL}$ soybean oil (Sp. Gravity: 0.9092) and allowed to stand at ambient temperature $\left(30 \pm 2^{\circ} \mathrm{C}\right)$ for $30 \mathrm{~min}$, the centrifuged for $30 \mathrm{~min}$ at $300 \mathrm{rpm}$ or $2000 \times \mathrm{g}$. Oil absorption was examined as mass water bound per gram flour.

The volume of $100 \mathrm{~g}$ of the flour was measured in a measuring cylinder $(250 \mathrm{~mL})$ after tapping the cylinder on a wooden plank until no visible decrease in volume was noticed, and based on the weight and volume, the apparent (bulk) density was calculated [6].

\section{Proximate Analysis of the Composite Wheat Flour}

The functionality of flours of wheat grains, which depends to a great extent on the starch and protein content of the flours, contribute a lot to the formulation and properties of the final product. Therefore, flours were analyzed for their functional properties. Particularly, the functional properties are required for the formulation of value-added composite bakery products. Protein (micro-Kjeldahl, Nx6.25), fat (solvent extraction) was also determined. The carbohydrate content was calculated by subtraction method.

\section{Moisture Content Determination}

The bread samples were determined by the AOAC [7] method. The bread samples were weighed into different crucibles. It was then placed in an oven at $105{ }^{\circ} \mathrm{C}$ for two hours, thirty and ten minutes respectively. Drying was stopped after obtaining a constant weight. The samples were cooled in a desiccator and weighed.

$\begin{array}{ll}\% \text { Moisture } & \text { Loss in weight } \\ \frac{\mathrm{W} 2-\mathrm{W} 3}{\mathrm{~W} 2-\mathrm{W} 1} \mathrm{X} 100 & \end{array}$ Where $\mathrm{W} 1=$ initial weight of empty crucible W2 = weight of empty crucible + sample before drying

W3 = final weight of empty crucible + sample after drying

\section{Ash Content Determination}

The ash contents were determined using the AOAC [7] method. Crucible were dried and cooled in dessicator before weighing. One gram of the bread samples was weighed into the crucible and the weight taken. The crucible containing the samples were placed into the muffle furnace and ignited at $500{ }^{\circ} \mathrm{C}$. For three hours. The muffle furnace was the allowed to cool, the crucibles were then brought out, cooled and weighed. The ash content was calculated as follows.

$$
\begin{aligned}
& \% \text { Ash }=\frac{\mathrm{W} 2-\mathrm{W} 1}{\text { Weight of sample }} \times 100 \\
& \mathrm{~W} 2=\text { weight of crucible }+ \text { ash } \\
& \mathrm{W} 1=\text { weight of empty crucible }
\end{aligned}
$$




\section{Fat Content Determination}

The fat content of the bread samples was determined using solvent extraction in a sohxlet apparatus as described by AOAC [7]. One gram of each sample was wrapped in a filter paper and placed in a sohxlet reflux flask which is connected to a condenser on the upper side and to a weighed oil extraction flask full with $400 \mathrm{~cm}^{3}$ of hexane. The hexane was brought to its boiling point, the vapour condensed into the reflux flask immersing the samples completely for extraction to take place on filling up the reflux flask siphons over carrying the extract back to the boiling solvent in the flask. The process of boiling, condensation and reflux was allowed to go on for hours before the defatted samples were removed. The oil extract in the flux was dried in the oven at $70^{\circ} \mathrm{C}$ for thirty minutes and then weighed.

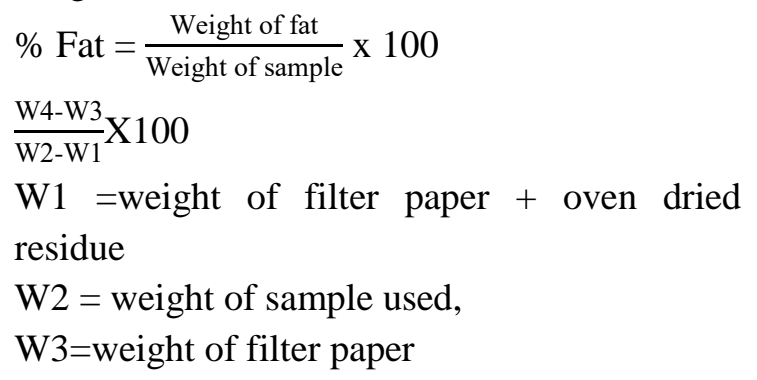

\section{Crude Fibre Determination}

The crude fibre of the bread samples were determined according to AOAC [7] method. Two grams of each of the samples were boiled under reflux in the fume cupboard for thirty minutes with $200 \mathrm{ml}$ of $15 \mathrm{~mL} \mathrm{H}_{2} \mathrm{SO}_{4}$. The solution was filtered through filter paper in a Buchner funnel using a vacuum pump and washed with distilled water unto neutrality. The residue was then transferred to a round bottom flask and boiled for thirty minutes with $100 \mathrm{ml}$ of $5 \% \mathrm{NaOH}$ solution. The final residue was filtered through a filter paper into a crucible washed with distilled water and ethanol unto neutrality. The residue was then dried in an oven and weighed. The residue was incinerated in a muffle furnace. Cooled and weighed.
$\%$ Crude fibre $=\frac{\mathrm{W} 2-\mathrm{W} 3}{\mathrm{~W} 1} \mathrm{X} 100$

$\mathrm{W} 1=$ weight of sample used

W2=weight of crucible + oven dried sample

W3=weight of crucible + ash

\section{Crude Protein Determination}

Crude Protein of the bread samples were determined using the kjedahl method. One gram of the sample was introduced into the digestion flask. $10 \mathrm{~mL}$ of $\mathrm{HNO}_{3}$ was added, heated and filtered and was made up to 100 mL. $10 \mathrm{ml}$ of digest was introduced into a 500 $\mathrm{ml}$ flask and diluted with $40 \mathrm{ml}$ distilled water. $40 \% \mathrm{NaOH}$ solution was added and stoppered very well with a condenser. It was connected to a $250 \mathrm{ml}$ conical flask. $4 \% 50 \mathrm{ml}$ boric acid was added to the $250 \mathrm{ml}$ conical flask. Heating was increased and the distillate collected. $0.1 \mathrm{~N} \mathrm{HCl}$ was titrated against the distillate to obtain a faint pink colour sample and the initial and final results were recorded and the average titre value was calculated and recorded. The percentage protein of the samples was obtained from the following analysis.

$\%$ nitrogen $($ wet $)=($ A-B $)$ X 1.4007X 100 Weight (g) of sample $\mathrm{A}=\mathrm{Vol}(\mathrm{ml}) \mathrm{Std} \mathrm{HCl}$ x Normality of Std $\mathrm{HCl}$ $\mathrm{B}=\mathrm{Vol}(\mathrm{ml}) \operatorname{Std} \mathrm{NaOH} x \quad$ Normality of Std $\mathrm{NaOH}$

$\%$ nitrogen $($ dry $)=\%$ nitrogen (wet) 100- \% moisture

$\%$ protein $=\%$ nitrogen $($ dry $) \times 6.25$ (protein nitrogen conversion factor)

\section{Carbohydrate Content Determination}

Carbohydrate content of the bread samples were determined using the AOAC [7] method. $\%$ carbohydrate $=100-\%$ (protein + fat + fibre + ash + moisture content).

\section{Results and Discussion}

The functional properties determine the application and use of food materials for various food products [8]. 
Table 1: Functional Properties of the Bread Sample

\begin{tabular}{|c|c|c|c|c|c|}
\hline Sample Code & $\begin{array}{l}\text { Bulk } \\
\left(\mathrm{g} / \mathrm{cm}^{3}\right)\end{array}$ & Density & $\begin{array}{l}\text { Oil Absorption } \\
\text { Capacity }(\mathrm{g} / \mathrm{g})\end{array}$ & $\begin{array}{l}\text { Water Absorption } \\
\text { Capacity }(\mathrm{g} / \mathrm{g})\end{array}$ & $\begin{array}{l}\text { Swelling Capacity } \\
(\mathrm{g} / \mathrm{g})\end{array}$ \\
\hline$\overline{\mathrm{AB}_{1}}$ & 0.60 & & 1.791 & 2.197 & 6.029 \\
\hline $\mathrm{AB}_{2}$ & 0.60 & & 1.626 & 2.503 & 5.764 \\
\hline $\mathrm{AB}_{3}$ & 0.59 & & 1.912 & 2.687 & 6.122 \\
\hline $\mathrm{AB}_{4}$ & 0.54 & & 2.150 & 3.044 & 6.894 \\
\hline $\mathrm{AB}_{5}$ & 0.60 & & 1.608 & 2.389 & 7.610 \\
\hline
\end{tabular}

\section{Swelling Capacity}

The swelling capacity of the bread ranged between 5.76 to $7.610 \mathrm{~g} / \mathrm{g}$. From Table 1, it is clear that, the lowest value of swelling capacity was observed in $\mathrm{AB}_{2}(5.764 \mathrm{~g} / \mathrm{g})$ and the maximum in $\mathrm{AB}_{5}(7.610 \mathrm{~g} / \mathrm{g})$. The value of swelling capacity was found for $\mathrm{AB}_{1}(6.029 \mathrm{~g} / \mathrm{g})$ $\mathrm{AB}_{3}(6.122 \mathrm{~g} / \mathrm{g})$ and $\mathrm{AB}_{4}(6.894 \mathrm{~g} / \mathrm{g})$. The swelling capacity of flours depends on size of particles, types of variety and types of processing methods or unit operations. High swelling power is an important criterion for good quality flour. The swelling power of flour granules is an indication of the extent of associative forces within the granule. Swelling power is also related to the water absorption index of the starch-based flour during heating.

As per literature, the flour of parboiled rice has more swelling capacity as compared to raw rice. Swelling capacity of composite flours increased with increase in the level of incorporation ratio of watermelon rind flour and decreased with level of wheat flour. The composite flour $\left(\mathrm{AB}_{5}\right)$ had the highest swelling capacity $(7.610 \mathrm{~g} / \mathrm{g})$ while $\mathrm{AB}_{2}$ $(5.764 \mathrm{~g} / \mathrm{g})$ had lowest values. It is explicit that the swelling capacity of composite flours is highly affected by the level of watermelon rind flour.

\section{Water Absorption Capacity (WAC, g/g)}

The water absorption capacity for composite flours is given in Table 1. The WAC ranged between 2.197 to $3.044 \mathrm{~g} / \mathrm{g}$ for all flours. The WAC was observed highest in $\mathrm{AB}_{4}(3.044 \mathrm{~g} / \mathrm{g})$ and lowest in $\mathrm{AB}_{1}(2.197 \mathrm{~g} / \mathrm{g})$. While composite flours $\mathrm{AB}_{2}, \mathrm{AB}_{3}$ and $\mathrm{AB}_{5}$ had 2.503, 2.687 and $2.389 \mathrm{~g} / \mathrm{g}$ WAC. From the present study, $\mathrm{AB}_{4}$ had highest WAC $(3.044 \mathrm{~g} / \mathrm{g})$. Water absorption in flour correlate positively with the amylose content and also particle size of the wheat flour [9]. High water absorption is desirable in flour. Water absorption capacity is an indication of the extent to which protein can be incorporated into food formulation. Increase in water absorption capacity implies high digestibility of the starch. The water absorption characteristic represents the ability of a product to associate with water under conditions where water is limiting, in order to improve its handling characteristics and dough making potentials [10]. The result suggests that addition of watermelon rind flour to wheat flour affected the amount of water absorption. This could be due to molecular structure of the watermelon rind flour which inhibited water absorption, as could be seen from the lower values of WAC, with increase in proportions of watermelon flour to wheat flours. Similar observation was reported by Kaushal et al. [11]. Kuntz [12] reported that lower WAC in some flours may be due to less availability of polar amino acids in flours. The increase in WAC of blends after incorporating watermelon rind flour may be due to increase in the amylose leaching and solubility and loss of starch crystalline structure.

High WAC of composite flours suggests that the flours can be used in formulation of some foods such as sausage, dough, processed cheese and bakery products. The increase in the WAC has always been associated with increase in the amylose leaching and solubility, and loss of starch crystalline structure. The flour with high water absorption may have more hydrophilic constituents such as polysaccharides. Protein has both hydrophilic and hydrophobic nature and therefore they can interact with water in foods. 
The good WAC of composite flour $\left(\mathrm{AB}_{4}\right)$ may prove useful in products where good viscosity is required such as soups and gravies. The observed variation in different flours may be due to different protein concentration, their degree of interaction with water and conformational characteristics [13].

\section{Oil Absorption Capacity (OAC, g/g)}

The OAC ranged between 1.608 to $2.150 \mathrm{~g} / \mathrm{g}$ among all the composite flour samples. The composite flours $\left(\mathrm{AB}_{4}\right)$ had highest $\mathrm{OAC}$ and lowest for $\mathrm{AB}_{5}(1.608 \mathrm{~g} / \mathrm{g})$ as compared to wheat flour $\mathrm{AB}_{1}(1.791 \mathrm{~g} / \mathrm{g})$. The presence of high fat content in flours might have affected adversely the OAC of the composite flours. The mechanism of oil absorption is attributed mainly to the physical entrapment of oil and the binding of the oil to the apolar chain of protein [14]. Low oil absorption is highly desirable as far as flour product is concerned. This functional property determines the amount of flour to make good dough. The above low oil absorption values of wheat/watermelon flours therefore suggest that they could be used for the production of bakery products.

Therefore, the possible reason for increase in the OAC of composite flours $A_{3}$ and $A_{4}$ after incorporation of watermelon rind flour is due to the variations in the presence of non-polar side chain, which might bind the hydrocarbon side chain of the oil among the flours. Similar findings were observed by Kaushal et al. [11]. However, the flours in the present study are potentially useful in structural interaction in food, especially in flavor retention, improvement of palatability and extension of shelf life particularly in bakery or meet products where fat absorption is desired [15]. The major chemical component affecting OAC is protein which is composed of both hydrophilic and hydrophobic parts. Non-polar amino acid side chains can form hydrophobic interaction with hydrocarbon chains of lipids [16].

\section{Bulk density $\left(\mathrm{g} / \mathrm{cm}^{3}\right)$}

The bulk density $\left(\mathrm{g} / \mathrm{cm}^{3}\right)$ of flour is the density measured without the influence of any compression. The bulk densities of the flours ranged from 0.54 to $0.60 \mathrm{~g} / \mathrm{cm}^{3}$. The highest highest bulk density was observed $\mathrm{AB}_{1}, \mathrm{AB}_{2}$ and $\mathrm{AB}_{5}$ flour respectively, with a value of $(0.60$ $\left.\mathrm{g} / \mathrm{cm}^{3}\right)$ followed by $\mathrm{AB}_{3}$ flour $\left(0.590 .60 \mathrm{~g} / \mathrm{cm}^{3}\right)$, and lowest was $\mathrm{AB}_{4}$ flour $\left(0.540 .60 \mathrm{~g} / \mathrm{cm}^{3}\right)$. The results of functional properties of wheat/watermelon flour are presented in Table 1 . Bulk density has been found to be a function of flour wetability [17]. Bulk density is an indication of the porosity of a product which influences packaging design and could be used to determine the type of packaging material required. It is also important in infant feeding where less bulk density is desirable [10]. Low bulk density flours are desirable for infant food preparation. The low bulk densities of wheat/watermelon flours therefore suggest they could be useful in infant formulations.

The present study revealed that bulk density depends on the particle size and initial moisture content of flours. The high bulk density of flour suggests their suitability for use in food preparations. On contrast, low bulk density would be an advantage in the formulation of complementary foods [18]. Therefore, present study suggests that highest bulk density of composite flour $\left(\mathrm{AB}_{1}, \mathrm{AB}_{2}\right.$ and $\left.\mathrm{AB}_{5}\right)$ suggests its suitability to be used as thickener in food products and for use in food preparation since it helps to reduce paste thickness which is an important factor in convalescent and child feeding. 
Table 2: Proximate Composition of Bread Sample

\begin{tabular}{llllllll}
\hline $\begin{array}{l}\text { Bread } \\
\text { Sample }\end{array}$ & Moisture (\%) & Ash (\%) & Fat (\%) & $\begin{array}{l}\text { Fibre } \\
(\%)\end{array}$ & $\begin{array}{l}\text { Protein } \\
(\%)\end{array}$ & $\begin{array}{l}\text { Carbohydra } \\
\text { te }(\%)\end{array}$ & $\begin{array}{l}\text { Energy value } \\
(\text { Kcal/100g) }\end{array}$ \\
\hline $\mathrm{AB}_{1}$ & 20.5 & 0.5 & 24.0 & 0.75 & 10.7 & 44.3 & 436.0 \\
$\mathrm{AB}_{2}$ & 18.3 & 0.6 & 18.4 & 1.55 & 15.7 & 47.1 & 416.6 \\
$\mathrm{AB}_{3}$ & 16.2 & 1.0 & 16.4 & 1.65 & 17.5 & 48.9 & 413.2 \\
$\mathrm{AB}_{4}$ & 14.0 & 1.2 & 15.5 & 1.75 & 18.6 & 50.7 & 416.7 \\
$\mathrm{AB}_{5}$ & 14.4 & 1.0 & 13.8 & 2.55 & 18.8 & 52.0 & 407.4 \\
\hline
\end{tabular}

Table 2, showed that the percentage protein content of $A B{ }_{1}$ to $\mathrm{AB}_{5}$ and was significantly different from the control sample. The percentage protein increased as the level of substitution increased. This may be due to the high water absorption capacity of the wheat flour which enabled the incorporation of protein from the watermelon rind flour [19], of course, it was observed that the percentage crude watermelon rind flour increased as the substitution level increased compared to the control sample which had no watermelon rind flour. The addition of dietary fibre to bakery products also improves their nutritional quality since it makes possible to decrease the fat content, by using dietary fibre as substitutive of fat without loss of quality [20, 21]. As can be seen in Table 2 above, the percentage fat content decreased with increase substitution level with $\mathrm{AB}_{5}$ (40\% rind fibre) having the lowest values of $\%$ fat. Therefore, for population seeking food with low fat content, $40 \%$ watermelon rind flour or more can be incorporated into the food for the desired $\%$ fat content. Generally, the ash content of composite bread samples increased as the level of substitution increased implying that watermelon rind flour positively impacted inorganic nutrients in composite bread. The carbohydrate content of the bread samples increased with increased substitution compared to control samples. This observation may be due to the higher carbohydrate content in the watermelon rind flour and the higher carbohydrate content in the bread makes it a quick source of metabolisable energy and assists in fat metabolism. Fibre-rich foods are lower in energy density [22]. The energy values of the bread samples decreased from 416.6 to $407.4 \mathrm{kcal} / 100 \mathrm{~g}$. Findings in this study suggest that bread could serve as source of energy for the metabolic process in the mammalian body.

The moisture content of cakes prepared with $10.0 \%, 20.0 \%, 30.0 \%$ and $40 \%$ substitution level of rind fibre were lower than that of control and the moisture content decreased with increasing substitution level [23]. The effect of increased water holding capacity by rind flour is due to the presence of high concentration of fiber components (cellulose, hemicellulose or pentosans, lignins and other dietary fiber components). The fibre contribute to the lower moisture content of the composite flour bread [23].

\section{Conclusion}

The study shows that watermelon rind flour addition into wheat flour bread formulation had considerable impact on the physical and chemical composition as well as the nutritional quality of bread and cake. It may be concluded from the present study that watermelon rinds can be successfully incorporated into wheat flour bread formulation up to a level of $10 \%$ to $30 \%$ to yield bread of enhanced nutritional quality instead of discarding them after eating the pulp. Hence, development and utilization of such functional foods will not only improve the nutritional status of the population but also helps those suffering from degenerative diseases. Incorporation of watermelon rind flour to wheat flour would therefore be an effective method of cost reduction of bread, cake and other allied products and solving malnutrition problems. 


\section{Acknowledgement}

Special thanks go to the Department of Chemistry, University of Benin, Benin City and to Prof. J.U. Iyasele of the Department of Chemistry, University of Benin, Benin City for his impactful, insightful and invaluable contributions.

\section{Recommendation}

More studies should be conducted to investigate the possibility of using watermelon rind fibre as an ingredient in other food products in order to increase applications of such value-added food ingredient.

\section{References}

1. D.A.V. Dendy (1993), Review of composite flour technology in the context of Tanzania. Present a paper at the workshop entitled 'Sorghum and millets marketing and utilization' held at Acrusha, Tanzania during 3-5 May, 1993.

2. J.E. Kinsella (1976), Functional properties of protein in food- A survey. Crit Rev Food Sci Nutr., 5, 219-225.

3. K.F. Mattil (1971), The functional requirement of protein in foods. $J$. Am. Oil Chem. Soc., 48, 477.

4. J.C. Okaka and N.N. Potter (1977), Functional and storage properties of cowpea-wheat flour blends in bread making. Journal of Food

Science, 42, 828-833.

5. F.W. Sosulski, M.O. Garatt and A.E. Slinkard (1976), Functional properties of ten legume flours. Intern J. Food Sci Technol., 9, 66-69.

6. D. Jones, R. Chinnaswamy, Y. Tan and M. Hanna (2000), Physiochemical properties of ready-to-eat breakfast cereals. Cereal Foods World, 45, 164168.

7. AOAC (2000), Official methods of analysis of AOAC International (17th edn.). Gaitherburg. USA: AOAC International Inc.

8. R.O. Adeleke and J.O. Odedeji (2010), Functional properties of wheat and sweet potato flour blends. Packer Journal on Nutrition, 9, 535-538.

9. I.A. Adeyemi and O. Beckley (1986), Effect of period of maize fermentation and souring on chemical properties and amyl grapy on millet biscuit characteristic. Plant Foods Human Nutrition, 56, 195-202.

10. M.O. Iwe and O.O. Onalope (2001), Effect of extruded full fat soy flour into sweet potato flour on

Functional properties of the mixture.

Journal of Sustain, Agriculture and

Environment, 3, 109-117.

11. P. Kaushal, V. Kumar and H.K. Sharma (2012), Comparative study of physicochemical, functional, anti-nutritional and pasting properties of taro (Colocasia esculenta), rice (Oryza sativa), pigeon pea (Cajanus cajan) flour and their blends. LWT-Food Sci Technol., 48, 59-68.

12. I.D. Kuntz (1971), Hydration of macromolecules III. Hydration of polypeptides J. Am. Chem. Society., 93, 514-515.

13. M.S. Butt and R. Batool (2010), Nutritional and functional properties of some promising legumes proteins isolates. Pakistan J. Nutr., 9(4), 373-379.

14. J.C. Wan and J.E. Kinsella (1991), Functional properties of novel protein, Alfalfa leaf protein. Journal Food Science, 41, 1183.

15. M.O. Aremu, O. Olaofe and E.T. Akintayo (2007), Functional properties of some Nigerian varieties of legume seed flour concentration effect on foaming and gelation properties. J. Food Technol., 5(2), 109-115.

16. S. Jitngarmkusol, J. Hongsuwankul and K. Tananuwong (2008), Chemical composition, functional properties and microstructure of defatted macademice flours. Food Chem., 110, 23-30.

17. F.N. Solsuki (1962), The centrifugal method for determining flour absorptive in hard red spring wheat.

Cereal Chemistry, 39, 344-346. 
18. M.I. Akapata and P.I. Akubor (1999), Chemical composition and selected functional properties of sweet orange (Citrus sinensis) seed flour. Plant Food Hum Nutr.

19. A.S. Bawa and G.S. Bains (1977), Integrated processing of watermelons for juice and seed Indian food packer, 31(6), 12-15.

20. M. Byrne (1997), Low-fat with taste. Food Engineering International, 22, 3641.
21. K. Martin (1999), Replacing fat, retaining taste. Food Engineering International, 24, 57-59.

22. B.J. Rolls, E.A. Bell, V.H. Castellanos, M. Chow, C.L. Pelkman, L.U. Thompson and R.G. Josse (1999), Energy density but not fat content of foods affected energy intake in lean and obese women. America Journal of Nutrition, 69(5), 863-871.

23. D. Dhingra (2012), Dietary fibre in foods: A review. Journal of Food Science Technology, 49, 255-266. 